\title{
Service of Excellence of DKI Jakarta Public Service Mall and Customer Satisfaction
}

\author{
Ridoni Daniel ${ }^{1}$, Suraya Mansur ${ }^{2}$ \\ \{daniel.ridoni@gmail.com¹, suraya.suraya@mercubuana.ac.id²\} \\ Mercu Buana University, Jakarta, Indonesia ${ }^{12}$
}

\begin{abstract}
Public service innovation by employing a one-stop integrated service concept through Jakarta Public Service Mall for the citizens of Jakarta. This research aims to find out the influence of excellent service and customer satisfaction. This research employed excellent service theory and explanatory quantitative methods. The conclusion is the excellent service influences the increase of citizens' satisfaction.
\end{abstract}

Keywords: service, satisfaction, perception, citizens, Jakarta

\section{Introduction}

The 1945 Constitution of the Republic of Indonesia orders the country to fulfill the basic needs of its people. Service is every action or activity offered by a certain party to another. Service is not provided in the form of goods and does not create any ownership to anyone [1]. An individual could not get away from public service affairs, including administration, health, education, and others. Public service is every activity held by the government as an effort to fulfilling the public's needs and implementing the Law. During the implementation of public service, the government is responsible for providing the best service to the citizens. Citizens have the right to receive the best service from the government due to the tax, retribution, and other collection paid. The statement is in line with the Law of the Republic of Indonesia No. 25 on 2009 on Public Service, that citizen has the rights to receive excellent service that is in line with the aim of the service. The main purpose of public service is the citizens' satisfaction and perception.

Excellent service means good service, following the service standard applied by an institution [2] [3]. Thus, excellent service is a form of service that can fulfill the customers' expectations. Service is essentially an activity offered by organization, company, or individual to others (customers). One of the government institutions that provide public service is the Jakarta Public Service Mall. It is a part of the main duty and responsibility of the One-Stop Integrated Service and Investment Service of DKI Jakarta. Based on the data gained from beritajakarta.id, since it was launched, the number of visitors keeps increasing from 300 visitors per day to 600-700 visitors per day [4]. Until today, the services provided in the Public Service Mall are 328. The services are in the form of a trade permit and a nontrade permit.

The customer service officers in the Jakarta Public Service Mall are active in using modern information technology to support the comfort and satisfaction in receiving service. A positive and comfortable atmosphere is created inside all the rooms in the Jakarta Public Service Mall. The effort was aimed to provide an excellent service for all; thus, the citizen 
would find themselves hanging around a mall or cozy supermarket when they are filing permits in Jakarta Public Service Mall. Based on the initial observation conducted, the citizen tends to encounter a difficult and inefficient bureaucracy in filing any business. Citizens receive mostly dissatisfactory service from both government and private institutions. The bad review for the dissatisfactory service received was expressed by the citizens through various ways, such as strong criticism (rally, articles, SMS President, and more) and constructive criticism (Negeri BBM Program in Indosiar, Negeri Sketsa in Radio Smart FM, the advertisement of Sampurna A Mild on television, and many more).

Public service according to the Law of the Ministry of Administrative and Bureaucratic Form No. 63 on 2004 on the General Guidelines of Public Service is "all service activities conducted by a public service provider to fulfill the needs of receiver or the implementation of the law". The essence of public service is providing excellent service to the citizens as the responsibility of the government institution. According to Article 5 of Law No. 25 on 2009 on Public Service, "the scope of public service covers public goods service and public service, including administrative service ordered by the law". The scope includes education, teaching, employment and trade, housing, communication and information, environment, health, insurance, energy, bank, transportation, natural resources, tourism, and other strategic sectors.

Public service is every activity conducted by the government to a certain community that has certain activity and offers satisfaction although the results are not attached to a certain physical product [5] [6]. Excellent service (also known as service excellence) is the best service in fulfilling the expectation and needs of customers. In other words, excellent service fulfills the quality standard requirement. The quality standard of excellent service is when the service could fulfill the expectation or satisfaction of the customers or public. [7] [8] [9]

Parasuraman, et al., identified ten quality dimensions of excellent service. The dimensions are (1) Reliability, it covers two main ideas, performance and dependability. The dimension means that the company provides the service accordingly right the first time. Besides, the company should fulfill its promises. (2) Responsiveness, which means the willingness or readiness of the employee or customer service officers to provide service needed. (3) Competence, which signifies the value that every individual in the company has certain competence, skills, and knowledge to provide service. (4) Access, this dimension covers being reachable and flexible. The dimension also implies that the location of the service facility is accessible and reachable through several mediums such as phone calls, online, and many more. (5) Courtesy, which covers manner, respect, attention, and hospitality that is also owned by the contact personnel (receptionist, call operators, etc.) (6) Communication, defined as the ability to provide information to customers in understandable language (7) Credibility, which means honest and trusted. Credibility covers the company's name, reputation, personal characteristics, contact personnel, and customer interaction. (8) Security, the service is safe from risk or doubt. This aspect covers physical safety, financial security, and confidentiality. (9) Understanding/Knowing the Customer, which is the effort to understand the needs of the customers. (10) Tangibles, which is the physical evidence of the service in the form of physical facilities, tools, and physical representation of the service (for instance, credit card). [10] [11] [12]

The Decree of the Ministry of Administrative and Bureaucratic Form No. 63 on 2003 on the General Guidelines of Public Service, mentioned that: (1) The simplicity (service procedure is efficient, understandable, and convenient). (2) Clarity (in providing information regarding the technical requirements and service administration, and the working unit that is responsible for providing service and solving issues, service charge receipt, and procedure). 
(3) Time Certainty (the service should be delivered in an estimated period or duration. (4) Accuracy (service is received properly and valid). (5) Security (the process and service provide safety and law security.) (6) Responsibility (the supervisor of the service is responsible for the service and solving provided during the activity). (7) Completeness (the facility that supports the service is provided, especially the facility that is related to communication technology). (8) Access (venue and facilities provided are proper and accessible for everyone). (9) Discipline, politeness, and friendliness (in providing service, the representatives should have a good manner, polite, and friendly). (10) Convenience (the environment or place where the service is provided should be clean, proper, healthy, and equipped with supporting facilities such as parking area, toilet, prayer room, and others).

Study on excellent service, citizens' perception, and satisfaction in the context of public service has been conducted on previous studies [13] [14] [15] [16] [17] [18] [19] [20] [21] [22] [23]. The focus of this study which is different than the others is the variable observed, the influence and relation between variables, and the location where the public service delivered. Thus, the research question is how excellent service influence the citizens' satisfaction on Jakarta Public Service Mall?

The hypothesis of this study is formulated as below:

H0: There is no influence or correlation between excellent service and citizens' satisfaction in Jakarta Public Service Mall.

H1: There is an influence of excellent service on citizens' satisfaction in Jakarta Public Service Mall.

\section{Research Method}

This study employed a positivist paradigm with a quantitative approach. The method of this study is an explanative survey. The population of this study is 7,167 visitors to Jakarta Public Service Mall in June 2019. The researcher used 100 respondents who have visited and filed permits in Jakarta Public Service Mall. The technique used in deciding the sample is non-probability sampling with purposive sampling. Purposive sampling is the technique to decide samples with a certain consideration [24]. The consideration in this study is those who have filed permits in Jakarta Public Service Mall could be chosen as the sample. The customers' responses data were gained using the Mail Chimp application that sent out an email of Google Form link to 1,894 receivers or around $25 \%$ of the total visitors of Jakarta Public Service Mall in June 2019. The email sent on Wednesday, 25th September 2019. Half of the population was chosen as the respondent since this explanatory study was conducted using a case approach, thus, the number of samples is the amount of filled questionnaire that is qualified to be processed.

This study employed a questionnaire in collecting data. The questionnaire was distributed to all citizens' who have filed permits in Jakarta Public Service Mall. The data quality test is the required test in this study with a questionnaire instrument to gain reliable data. The test consists of validity and reliability test, with the results below:

Table 1. The Results of Validity Test of Excellent Service, Citizens' Perception, and Satisfaction

\begin{tabular}{cccc}
\hline Variable & Indicator & $\begin{array}{c}\text { Product Moment Correlation } \\
\left(\mathrm{r}_{\mathrm{xy}}\right)\end{array}$ & Information \\
\hline Excellent & $\mathrm{X} 1$ & 0,781 & Valid
\end{tabular}




\begin{tabular}{|c|c|c|c|}
\hline \multirow[t]{9}{*}{ Service (X) } & $\mathrm{X} 2$ & 0,833 & Valid \\
\hline & $\mathrm{X} 3$ & 0,803 & Valid \\
\hline & $\mathrm{X} 4$ & 0,876 & Valid \\
\hline & X5 & 0,839 & Valid \\
\hline & X6 & 0,868 & Valid \\
\hline & $\mathrm{X7}$ & 0,841 & Valid \\
\hline & $\mathrm{X} 8$ & 0,863 & Valid \\
\hline & X9 & 0,503 & Valid \\
\hline & $\mathrm{X} 10$ & 0,589 & Valid \\
\hline \multirow{6}{*}{$\begin{array}{c}\text { Citizens' } \\
\text { Perception (Z) }\end{array}$} & $\mathrm{Z1}$ & 0,860 & Valid \\
\hline & $\mathrm{Z} 2$ & 0,745 & Valid \\
\hline & $\mathrm{Z3}$ & 0,773 & Valid \\
\hline & $\mathrm{Z} 4$ & 0,791 & Valid \\
\hline & $\mathrm{Z} 5$ & 0,917 & Valid \\
\hline & Z6 & 0,906 & Valid \\
\hline \multirow{8}{*}{$\begin{array}{c}\text { Citizens' } \\
\text { Satisfaction (Y) }\end{array}$} & Y1 & 0,578 & Valid \\
\hline & Y2 & 0,765 & Valid \\
\hline & Y3 & 0,700 & Valid \\
\hline & Y4 & 0,552 & Valid \\
\hline & Y5 & 0,622 & Valid \\
\hline & Y6 & 0,814 & Valid \\
\hline & Y7 & 0,716 & Valid \\
\hline & Y8 & 0,552 & Valid \\
\hline
\end{tabular}

The reliability test is related to the stability level of the questionnaire, which means that the questionnaire can provide stable answers from time to time if it was given again to the same respondents.

Table 2. The Results of Reliability Test of the Study Instrument

\begin{tabular}{cccc}
\hline Variable & Indicators/Question Item & $\begin{array}{c}\text { Cronbach } \\
\text { Alpha }\end{array}$ & Information \\
\hline Quality of Service & 10 question items & 0.925 & Reliable \\
Citizens' Perception & 6 question items & 0.899 & Reliable \\
Citizens' Satisfaction & 8 question items & 0.805 & Reliable \\
\hline
\end{tabular}

The results show that the Cronbach Alpha value of every variable is always greater than 0.7. Thus, the variable of quality of service, citizens' perception, and citizens' satisfaction is said reliable. Data were analyzed using the inferential statistic. This study also employed linear regression analysis to measure the influence of an independent variable $(\mathrm{X})$ to the dependent variable(s) (Y).

\section{Results and Discussion}

The respondents who received questionnaires through email are 1,894 or $25 \%$ of the total customers of Jakarta Public Service Mall in June 2019. It was found that 638 was opened, 167 was read by the respondents, and 601 emails were bounced from Wednesday, 25th September 2019 to 30th September 2019. From 167 emails that have been read by the 
respondents, 127 respondents filled out the questionnaire. However, there are only 100 questionnaire data results that could be processed. The rest could not be processed due to the absence of permit columns and mistakes in filling out the questionnaire by the respondents themselves. The analysis was conducted to determine the profile of the respondents who had answered the questionnaire, such as their names, gender, age, educational background, and the number of visits to Jakarta Public Service Mall, and the type of permit filed.

Table 3. Characteristics of Respondents

\begin{tabular}{|c|c|c|c|c|c|c|}
\hline No. & \multicolumn{6}{|c|}{ General Description of the Respondents } \\
\hline \multirow[t]{3}{*}{1} & \multicolumn{6}{|c|}{ Gender } \\
\hline & Male & & & $52 \%$ & & \\
\hline & Female & & & $48 \%$ & & \\
\hline \multirow[t]{4}{*}{2} & \multicolumn{6}{|c|}{ Age } \\
\hline & & $\begin{array}{l}\text { 20-30 years } \\
\text { old }\end{array}$ & $\begin{array}{c}31-40 \text { years } \\
\text { old }\end{array}$ & $\begin{array}{l}41-50 \text { years } \\
\text { old }\end{array}$ & $\begin{array}{c}51-60 \\
\text { years old }\end{array}$ & $\begin{array}{l}70 \text { years } \\
\text { old above }\end{array}$ \\
\hline & Male & $15 \%$ & $9 \%$ & $12 \%$ & $15 \%$ & $1 \%$ \\
\hline & Female & $24 \%$ & $7 \%$ & $10 \%$ & $6 \%$ & $1 \%$ \\
\hline \multirow[t]{5}{*}{3} & \multicolumn{6}{|c|}{ Educational Background } \\
\hline & & & & Bachelor & Master & \\
\hline & & High School & Diploma & Degree & Degree & \\
\hline & Male & $10 \%$ & $10 \%$ & $26 \%$ & $6 \%$ & \\
\hline & Female & $5 \%$ & $6 \%$ & $29 \%$ & $8 \%$ & \\
\hline \multirow[t]{4}{*}{4} & \multicolumn{6}{|c|}{ Occupation } \\
\hline & & $\begin{array}{l}\text { Employee } \\
\text { of Private } \\
\text { Company }\end{array}$ & Student & Civil Servant & $\begin{array}{l}\text { Unemploy } \\
\text { ed }\end{array}$ & $\begin{array}{c}\text { Entrepren } \\
\text { eur }\end{array}$ \\
\hline & Male & $32 \%$ & $4 \%$ & $3 \%$ & $1 \%$ & $12 \%$ \\
\hline & Female & $32 \%$ & $9 \%$ & $1 \%$ & $2 \%$ & $4 \%$ \\
\hline \multirow[t]{4}{*}{5} & \multicolumn{6}{|c|}{ Number of Visit } \\
\hline & & Once & Twice & $\begin{array}{l}\text { More than } \\
\text { twice }\end{array}$ & & \\
\hline & Male & $13 \%$ & $4 \%$ & $35 \%$ & & \\
\hline & Female & $20 \%$ & $4 \%$ & $24 \%$ & & \\
\hline \multirow[t]{4}{*}{6} & \multicolumn{6}{|c|}{ Type of Permit } \\
\hline & & Private & Trade & Building & Land & \\
\hline & Male & $17 \%$ & $14 \%$ & $10 \%$ & $11 \%$ & \\
\hline & Female & $30 \%$ & $13 \%$ & $1 \%$ & $4 \%$ & \\
\hline
\end{tabular}

On table 3 , the percentage of the male respondent is greater $(52 \%)$ than female $(48 \%)$. The most age group is $20-30$ years old which consists of $15 \%$ male and $24 \%$ female. Furthermore, based on educational background, most of the respondents are bachelor graduates which consist of $26 \%$ male and $29 \%$ female. Related to the occupation, most of the respondents are employees of a private company (32\%) which consists of $32 \%$ male and $32 \%$ female. Most of the respondents have visited Jakarta Public Service Mall more than twice, which consists of $35 \%$ male and $24 \%$ female. Related to the type of permit, most of the respondents filed private permit (driver's license, vehicle registration, and identity card) which consist of $17 \%$ male and $30 \%$ female. 
Based on the characteristic of the age group, 50 respondents are $\mathrm{Y}$ generation or millennials (25-39 years old), 22 respondents are $\mathrm{X}$ generation (40-50 years old), and 23 respondents are baby boomer generation (51-60 years old). The generation classification used is based on Generation Theory by Graeme Codrington and Sue Grant Marshall, who proposed five human generations based on the birth year, those are baby boomer generation (born in 1946-1964), X generation (1965-1980). Y generation (1981-1994), Z generation or iGeneration (1995-2010), and Alpha generation (2011-2025) [25].

Based on the results obtained, excellent service variable (x variable) gained a total score of $82.56 \%$ which is classified as high. The dimensions employed by excellent service variable are Attitude, Ability, Action, Attention, Responsible, and Appearance where each dimension gained scores as below:

Table 4. Excellent Service Dimension (X)

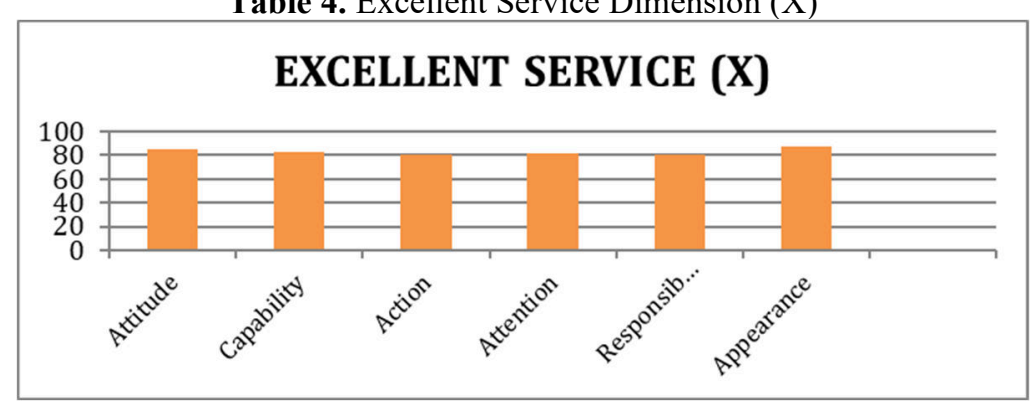

Most of the respondents (85.25\%) are satisfied with the service, where their needs and expectation were fulfilled. In this case, the quality is based on a good service, which is represented by attitude or how the officers provide service to the customer. Jakarta Public Service Mall has working culture applied to all officers, which is 3S, Senyum, Salam, Sapa (slogan of giving smile and greetings attitude). Most of the respondents $(82.25 \%)$ agree that the officers of Jakarta Public Service Mall have the ability to provide credible service. The credibility, friendliness, and attitude of the officers have ensured the citizens. Besides, they are also able to utilize supporting facilities in providing the service. Most of the respondents $(80.75 \%)$ appreciated various actions of the officers in fulfilling satisfaction. High quality of human resources is indicated by the problem-solving ability of the officers.

Most of the respondents (81\%) are pleased with the warm and personal attention given by the officers of Jakarta Public Service Mall. They are willing to allocate a mannerly time to listen and solve the issues. This characteristic is in line with an expectation of excellent service where public service is expected to have understanding and knowledge on its customers or citizen, including their needs specifically and convenient operational hours. Most of the respondents (79.75\%) perceived awareness of the officers to conduct service as excellent as possible. Jakarta Public Service Mall has a service procedure board put in the front office to communicate about their service procedure information to the customers or citizens. The officers of Jakarta Public Service Mall solved the issue in line with the procedure in a mannerly time, although they still need a longer time to solve the documents. Most of the respondents $(86.75 \%)$ found the waiting room as convenient. The officers greeted them warmly and the room is always clean, neat, and nice. The room is also equipped with television, newspaper, sweets, mineral waters, computers, and free internet access. 
Table 5. Citizens' Satisfaction Dimension (Y2)

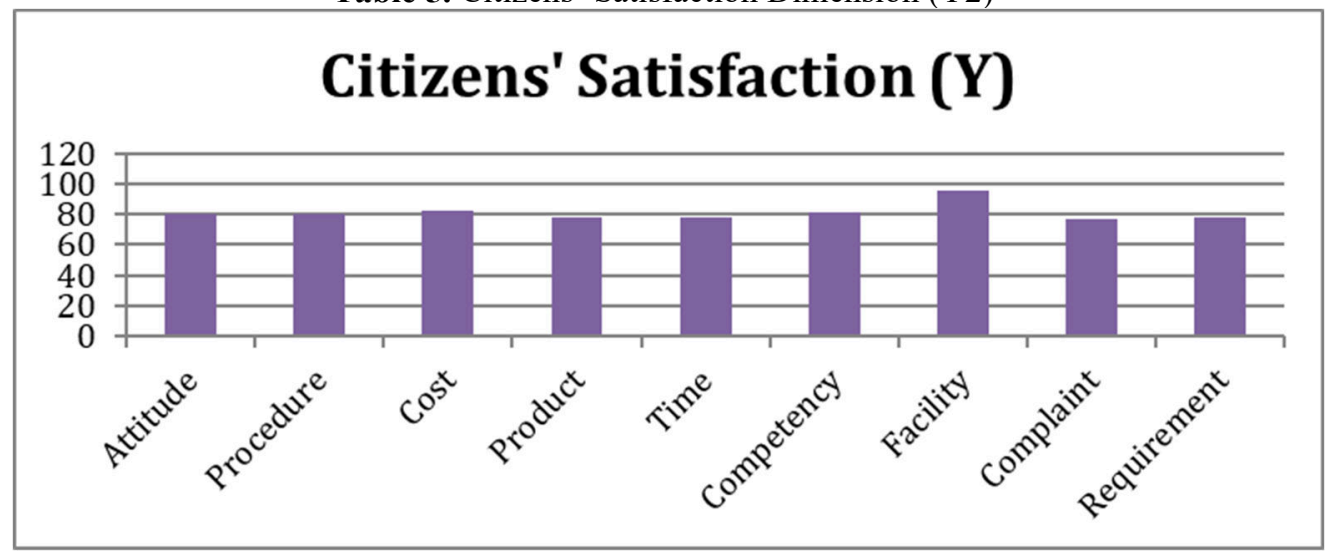

Respondents are satisfied (80\%) with the attitude of the officers of Jakarta Public Service Mall in providing service to the citizens' politely and friendly with full of appreciation and respect. Respondents are satisfied $(80 \%)$ because they found it easier to receive information regarding service procedure and flow steps in Jakarta Public Service Mall. Respondents are satisfied $(82 \%)$ because the service rate in Jakarta Public Service Mall is affordable and reasonable. Besides, the respondents are also satisfied $(77.74 \%)$ because the information given about the product is clear and understandable. Respondents are satisfied (78.25\%) because the information regarding the solving time estimation is clear and provided in Jakarta Public Service Mall. The solving time of permit license is following the regulation. The respondents are satisfied (81.5\%) with the officers' ability, knowledge, competencies, and experience. Respondents are highly satisfied $(95.25 \%)$ with the convenience of the service environment of Jakarta Public Service Mall. The room is clean, neat, and nice.

The respondents are satisfied (77.25\%) with information regarding feedback, critics, and complaints handling standards. The respondents also found it easier to access the service in Jakarta Public Service Mall. Characteristic included in the competency dimension is $77.75 \%$, which is categorized as strong and proved that the respondents are satisfied because the service criteria are following the service type requested. Through the data obtained, it is concluded that respondents are satisfied with the excellent service provided by the officers of Jakarta Public Service Mall which was supported by appropriate supporting facilities. The stimulus given by the officers will receive positive feedback if the citizens can interpret and register positively to the service given. The Regression Test of Excellent Service with Citizens' Satisfaction is presented on the table below:

Table 6. Regression Test

Coefficients ${ }^{a}$

\begin{tabular}{|c|c|c|c|c|c|c|}
\hline \multirow[b]{2}{*}{ Model } & & \multicolumn{2}{|c|}{ Unstandardized Coefficients } & \multirow{2}{*}{$\begin{array}{c}\text { Standardized } \\
\text { Coefficients } \\
\text { Beta }\end{array}$} & \multirow[b]{2}{*}{$t$} & \multirow[b]{2}{*}{ Sig. } \\
\hline & & B & Std. Error & & & \\
\hline \multirow[t]{2}{*}{1} & (Constant) & 5.152 & 1.349 & & 3.819 & .000 \\
\hline & LAYANAN PRIMA & .662 & .037 & .876 & 17.982 & .000 \\
\hline
\end{tabular}

a. Dependent Variable: KEPUASAN MASYARAKAT 
The table above explained that $\mathrm{a}=$ constant value of unstandardized coefficients. The constant value of this case is 5.152. The value is constant which means if there is no excellent service $(\mathrm{X})$, the consistency value of Citizens' Satisfaction $(\mathrm{Y})$ is $5.152 . \mathrm{b}=$ the value of the regression coefficient. The $b$ value of this case is 0.662 which means that every $1 \%$ of addition in excellent service $(\mathrm{X})$ will result in an increase of 0.662 in Citizens' Satisfaction (Y2). Since the regression coefficient value is plus $(+)$, it can be said that excellent service (X) positively influenced the Citizens' Satisfaction (Y2). Thus, the regression equation is $\mathrm{Y}=5.152+0,662 \mathrm{X}$.

Table 7. Regression Model Summary

\begin{tabular}{l|l|r|r|r}
\multicolumn{7}{c}{ Model Summary } \\
Model & R & R Square & \multicolumn{1}{c}{$\begin{array}{c}\text { Adjusted } R \\
\text { Square }\end{array}$} & $\begin{array}{c}\text { Std. Error of } \\
\text { the Estimate }\end{array}$ \\
\hline 1 & $.876^{\mathbf{a}}$ & .767 & .765 & 1.825 \\
\hline
\end{tabular}

a. Predictors: (Constant), LAYANAN PRIMA

Through the output above, it was found that the value of $\mathrm{R}$ square is 0.318 . The value means that the influence of excellent service (X) on Citizens' Satisfaction (Y2) is $76.7 \%$ while $23.3 \%$ of the citizens' satisfaction is influenced by other variables that were not observed. Based on the analysis conducted, the hypothesis proposed is valid, that the officers who are competent in providing and delivering service influence the citizens' perception and satisfaction. The effective contribution of service officer competency to the perception and satisfaction of the citizens has the greatest correlation with the value of 6.272 . The results of the descriptive analysis of this study showed that $81.5 \%$ of the citizens agree that the officers possess capability which covers knowledge, skills, and experience in assisting permit applicants. The capability has produced the citizens' or customers' satisfaction. The results explained that competent officers have high factors to be related to the citizens' satisfaction. The performance of excellent service could improve the citizens' satisfaction because the performance is related to the service products (process, attitude, facilities, and service environment) which were adjusted to the needs of the citizens to bring satisfaction as a result.

The results of this study are in line with the results of a previous study conducted by the scholars of Kanjuruhan University Malang that excellent service influences the public's satisfaction [26]. An excellent service could improve the perception and satisfaction of the citizens when the officers could assist the customers well in BNI Syariah Malang (respond quickly to the complaint and completely understand the needs of the customers) [27]. Similar studies also explained that there is a significant relationship between public service quality performance and the citizens' satisfaction [28] [29] [30]. Competency has a positive correlation with the organization's performance. That was proven by the study that competency is correlated to a very strong category which means by improving the competency, the organization's performance will improve as well. The organization's performance is the description of the result of the organization's work and presented by how the activities were conducted to reach the aim of the organization. [31] [32].

Based on the analysis results, the respondents are mostly 25-39 years old and classified into the Y Generation or millennials. The generation has utilized instant communication technology such as email, SMS, instant messaging, and social media (Facebook, Instagram, and Twitter). They are also interested in online games [33]. The Y Generation tends to utilize the service of Jakarta Public Service Mall because the service is conducted by the 
government based on information technology and effective and efficient communication by utilizing social media. The officers are quick in responding and solving the problem or inquiries asked by the customers. Public Service provided by Jakarta Public Service Mall has an intensity in utilizing advanced communication and information technology to provide service.

Prior to this era, public service was portrayed in a form of disorganization, imbalance, not efficient, and related to bribery. Furthermore, the quality of public service was seen as arrogant, lack of sympathy, and overbearing. Service was built without seriousness and tend to complicate the society as the party who needed the service. Thus, the public was not assisted and tend to avoid public service due to the bad quality of the service. Information regarding service provided by public service is mostly conducted manually, especially information about a service procedure, administration requirement, cost of service, and duration. Information was presented using billboards, brochures, pamphlets, or information boards installed in the service room. During this disruption era, the information presentation method has been left behind and replaced by open and online information presentations through websites or applications in smartphones. Today's public service also utilizes the advancement of technology for easier access to the public or citizens. The presence of the information board is also limited and replaced by a digital screen showing information.

\section{Conclusion}

Excellent Service positively influences the citizens' satisfaction (Y2) with the total influence of 66.2\%", which covers dimension to the competency with the indicator that the officers possess skill, knowledge, and experience in assisting the citizen who visits Jakarta Public Service Mall. The positive influence means that excellent service provided could bring positive satisfaction as a result.

\section{References}

[1] P. Kotler, Hermawan Kartajaya, \& Iwan Setiawan,Marketing 4.0: Moving from Traditional to Digital. United States: Wiley, 2016.

[2] The importance of excellent customer service, BSI Group, London, United Kingdom, 2014, pp. 1-4.

[3] G. E. Zuriff. "7. Organization of Behavior," Behaviorism: a Conceptual Reconstruction. Edition 720.71, pp. 119-149, 2019.

[4] E. Martiyanti, "Per Hari, Mal Pelayanan Publik Dikunjungi 700 Warga," Berita Jakarta, 10 December 2017. In : http://www.beritajakarta.id/read/52821/per-hari-mal-pelayanan-publikdikunjungi-700-warga [14 June 2020].

[5] P. Ramseook-Munhurrun, Soolakshna D. Lukea-Bhiwajee, \& Perunjodi Naidoo."Service quality in the public service,"International Journal of Marketing and Marketing Research.Volume 3, Number 1, pp. 37-50, 2010.

[6] G. A. Boyne,"What is public service improvement?"Public Administration. Volume 81, Issue2, Pages 211-227, June 2003.

[7] J. Wirtz \& Valarie Zeithaml. "Cost-effective service excellence," Journal of the Academy of Marketing Science. Vol. 46, pp. 59-80, August 2017.

[8] M. Gouthier, Andreas Giese, \& Christopher Bartl, "Service excellence models: A critical discussion and comparison,"Managing Service Quality.Vol. 22 No. 5, pp. 447-464, 31 August 2012. 
[9] R. Johnston,"Towards a better understanding of service excellence,"Managing Service Quality: An International Journal. Vol. 14 No. 2/3, pp. 129-133, 1 April 2004.

[10] M. Morais Pena, Edenise Maria Santos da Silva, Daisy Maria Rizatto Tronchin, \&Marta Maria Melleiro. "The use of the quality model of parasuraman, zeithaml and berry in health services,"Revista Da Escola de Enfermagem. Vol.47 no.5, October 2013.

[11] A. Parasuraman, Zeithaml, V. A., \& Arvind Malhotra. "E-S-QUAL a multiple-item scale for assessing electronic service quality,"Journal of Service Research. Volume: 7 issue: 3, page(s): 213-233, 1 February 2005.

[12] A. Parasuraman, "Service productivity, quality and innovation: Implications for service-design practice and research,"International Journal of Quality and Service Sciences. Vol. 2 No. 3, pp. 277-286, 19 October 2010.

[13] R. K. Yeo \& Jessica Li. "Beyond SERVQUAL: The competitive forces of higher education in Singapore," Total Quality Management and Business Excellence. Vol. 25 Issue 1-2, pp. 95123, 13 January 2012.

[14] V. A. Zeithaml. "Service excellence in electronic channels," Managing Service Quality: An International Journal. Vol. 12 No. 3, pp. 135-139, 1 June 2020.

[15] M. Ali \&Syed Ali Raza,"Service quality perception and customer satisfaction in Islamic banks of Pakistan: the modified SERVQUAL model,"Total Quality Management and Business Excellence. Volume 28, 2017 - Issue 5-6, Pages 559-577, 5 Nov 2015.

[16] H. Hsin Chang,Yao-Hua Wang, \&Wen-Ying Yang, "The impact of e-service quality, customer satisfaction and loyalty on e-marketing: Moderating effect of perceived value," Total Quality Management \& Business Excellence. Volume 20, Issue 4, Pages 423-443, 20 April 2009.

[17] R. K. Yeo. "Servicing service quality in higher education: Quest for excellence," On the Horizon. Vol. 16 No. 3, pp. 152-161, 15 August 2008.

[18] H.S Sandhu \& Neetu Bala. "Customers' Perception towards Service Quality of Life Insurance Corporation of India: A Factor Analytic Approach," International Journal of Business and Social. Vol. 2 No. 18, pages 219-231, October 2011.

[19] S. Bashir, Irshad Hussain Sarki, \& Juhari Samidi,"Students' perception on the service quality of Malaysian universities' hostel accommodation,"International Journal of Business and Social Science.Vol. 3 No. 15, Pages 213-222, August 2012.

[20] E. Sadeh \& Mansour Garkaz. "Explaining the mediating role of service quality between quality management enablers and students' satisfaction in higher education institutes: the perception of managers," Total Quality Management and Business Excellence. Volume 26, 2015 - Issue 11-12, Pages 1335-1356, 4 July 2014.

[21] A. S. \& Sonal Devesh,"Service quality dimensions and customer satisfaction: empirical evidence from retail banking sector in Oman,"Total Quality Management and Business Excellence. Volume 30, 2019 - Issue 15-16, Pages 1616-1629, 21 Nov 2017.

[22] M. Akdere, Mehmet Top \&Sabahattin Tekingündüz,"Examining patient perceptions of service quality in Turkish hospitals: The SERVPERF model,"Total Quality Management and Business Excellence, Volume 31, 2020 - Issue 3-4, Pages 342-352, 21 January 2018.

[23] P. Tzong Jan, Hsi-Peng Lu, \& Tzu-Chuan Chou, "Measuring the perception discrepancy of the service quality between provider and customers in the Internet Protocol Television industry," Total Quality Management \& Business Excellence. Volume 23, 2012 - Issue 7-8: e-Services Quality, Satisfaction, Behaviors and Loyalty, pages 981-995, 8 May 2012.

[24] Sugiyono. Metode Penelitian: Kuantitatif, Kualitatif, dan R\&D, Bandung: Alfabeta, 2009.

[25] Marshall, Graeme Codrington, \& Sue Grant. Mind the Gap!, London: Penguin Group, 2011.

[26] C. Frisdiantara \&Andi $\mathrm{Nu}$ Graha, "Pengaruh Dimensi Pelayanan Dan Dimensi Fasilitas Terhadap Kepuasan Mahasiswa Pada Universitas Kanjuruhan Malang," Jurnal Ekonomi Modernisasi. Vol. 9 No. 2, Pages 106-119, 1 June 2013.

[27] H. Al Kanzu\&Harry Soesanto, "Analisis Pengaruh Persepsi Kualitas Pelayanan dan Perceived Value Terhadap Kepuasan Religius Untuk Meningkatkan Minat Menabung Ulang (Studi Pada BNI Syariah Semarang),"Jurnal Studi Manajemen Organisasi, Vol 13, No 1, 1 Jul 2016.

[28] F. Rangkuti. Customer Service Satisfaction \& Call Center Berdasarkan ISO 9001. Jakarta: 
Gramedia Pustaka Utama, 2003.

[29] A. S. \& Sonal Devesh,"Service quality dimensions and customer satisfaction: empirical evidence from retail banking sector in Oman,"Total Quality Management and Business Excellence. Volume 30, 2019 - Issue 15-16, Pages 1616-1629, 21 Nov 2017.

[30] R.B Vukmir. "Customer satisfaction," International Journal of Health Care Quality Assurance Vol. 19 No. 1, pp. 8-31, 1 January 2006.

[31] U. Sriwidodo \& Agus Budhi Haryanto. "Pengaruh Kompetensi, Motivasi, Komunikasi Dan Kesejahteraan Terhadap Kinerja Pegawai Dinas Pendidikan," Jurnal Manajemen Sumberdaya Manusia. Vol. 4 No. 1, pages 47 - 57, June 2010.

[32] R. Domínguez Martín, "The Importance of Communication Competency for Employability,"Procedia - Social and Behavioral Sciences. Volume 139, Pages 387-394, 22 August 2014.

[33] Marshall, Graeme Codrington, \& Sue Grant. Mind the Gap!, London: Penguin Group, 2011. 